UDC 339.137.22

JEL Classification: P42

Tkachenko A.M. ${ }^{a}$, Kolesnik E.O. ${ }^{b}$

\title{
THE CONCEPT AND NATURE OF THE FORMATION OF COMPETITION IN AN INDUSTRIAL ENTERPRISE
}

\author{
a Zaporizhzhya National Technical University, Zaporizhzhya, Ukraine \\ ${ }^{b}$ Classical private university Zaporizhzhya, Ukraine
}

\begin{abstract}
The article is devoted to the research of theoretical aspects of competition and its role in market conditions. The main approaches to the methodology of research of competition and competitiveness of enterprises are analyzed. The main types and functions of competition in modern conditions are considered. The factors influencing the formation of competition are determined. The factors that influence competition in market conditions are analyzed. The law of competition is considered. The competitive advantages are analyzed. The article states that the competitiveness of the enterprise is a complex variable concept, which means rivalry, struggle for achievement of the best results, obtaining competitive advantages by effectively using all available resources, manufacturing and realization of competitive products and making profit from conducting effective economic activity. In general, competitiveness is one of the main components of the success of any enterprise.
\end{abstract}

Keywords: competition, market, contest, competitiveness of enterprises, market mechanisms, competitive advantages.

DOI: $10.32434 / 2415-3974-2018-8-2-92-96$

\section{Formulating of the problem}

For any commodity producer, in the current conditions, regarding the growth of competition, the problem of not only storage, but also the use of modern levers to increase the personal competitiveness of a particular business entity, comes forefront. Managers at the top management positions are responsible for search of modern management tools, and the corresponding vectors of the introduction of innovative mechanisms for the formation of competitive advantages. A business entity cannot be able to achieve commercial progress in the modern market, to maintain its own positions and privileges in a competitive environment, if it does not formulate for itself, which is the priority in its specification.

\section{Analysis of recent research}

Key approaches to the methodology of competition and competitiveness research are established in the writings of such economists as I. Ansoff, M. Porter, D. Ricardo, A. Smith, J. Schumpeter. Different problems of economic competition as a social economic phenomenon are investigated in the works of V. Heyets, G. Azoyev, L. Antonyuk, Y.Bazylyuk, R. Fatkhutdinov, A. Yudanov, Pozhueva T.A. and other scientists. However, despite the large number of works and studies devoted to this issue, there is still no clear, generally accepted definition of competition and competitiveness.

The purpose of this article is to study the concept of «competition», its functions and definition of «competitiveness of the enterprise».

\section{Presenting main material}

The study of the concept of «enterprise competitiveness» involves clarifying the nature of the "competition", because they are closely interconnected - competitiveness can only be said when there is competition between producers of certain products (services).

Competition (from lat. concurentia - collision, rivalry) is a contest between business entities for more efficient, economically favorable conditions of production and sales [1, p.114]. Competition encourages commodity producers not to stand still, but to continuously improve themselves, reduce production costs, improve the quality of products (services) that are offered to the market, and increase their competitiveness.

Competition is a major factor in the regulation of a market economy and a significant share of the market environment of the business entities. The consequence of competition is, on the one hand, the complication of industrial and market relations, and 
on the other increase in effective economic activity.

Competition relates to uncontrollable factors that are not able to manage an enterprise. The definition of «competition» relates to such definitions as «market» and «commodity production». Competitive relations appeared in one period with market, but the initial theoretical positions of competition were determined only in the 18th century by followers of classical political economy. Competition arises with the emergence of commodity production. It is worth to mention that commodity production is a form of organization of social production in which products are produced for exchange. In this case, the products of labor, which they exchange, become goods [2, p.368]. Manufacturers here specialize in the manufacture of certain products, which necessitates the exchange in the form of sales on the market.

The market is an adapted system of economic (techno-economic, organizational, economic and economic property) relations between subjects of different types and forms of ownership and management within the boundaries of individual countries and the world economy with regard to the purchase of goods and services in accordance with the laws of commodity production [3, p.656].

Competition is a necessary and rather important aspect of a market economy, but the principles and structure of it in different markets are not the same. A significant system of economic interactions between producers and consumers in a market economy is competition. Competition is linked with certain costs (with the increase of socio-economic differentiation in the community), it satisfies a significant economic result, stimulates price reductions, improves the quality and range of manufactured goods, and implements scientific and technical results [4, p.86].

One of the regulators of total production ratio is economic competition, which encourages its effectiveness, is a factor in the creation of average profit rate, the formation of market value of products, distribution of producers for profit, realization of material interest of producers of goods. In all its specific manifestations, competition as a mechanism for the successful functioning of a market economy is based on the appropriateness and sequence and does not contradict the main vectors of the progress of productive capacities. Competition - the economic course of interaction and an encounter between business entities that are on the market in order to meet the best opportunities for selling their products, fulfilling the various needs of consumers and obtaining the highest profit [5, p. 95].

Significant legitimacy, which in practice acts as a consequence of economic competition of economic entities, is the continuous acceleration of the processes of modernization of production. Thus, competition requires a rigorous technological order, requires quality products, and modern design of products. In spreadsheet below the systematization of the notion of «competition» presented by different authors is considered.

Competition is a significant motivational force in the process of growth of the economic system, an integral part of its economic system, becoming an economic foundation, which requires clear regulation on the part of the state, reflected in the legislative documents. In the structure of competition, it is necessary to separate civilized and uncivilized methods. Non-civilized competition built on the use of harsh, ruinous methods, which intend to eliminate competitors (price war, threats, killings, etc.). The civilized competition is fair (the best price of products, an increase in the customer service network, a large amount of advertising, etc.). Unfair competition is defined in the same way as any actions that are contrary to the rules, trade and other fair practices in the business operation, and predict such methods as economic, technological and financial harassment, copying of branded goods, use of their trademark, enticement on their side leading workers, fraud with documents. All considered approaches to competition are interconnected in their combination, forming a competitive industry that carries out responsibilities in a market economy.

The essence of competition can also be

\begin{tabular}{l|l}
\hline \multicolumn{1}{c|}{ Author } & \multicolumn{1}{c}{ Determination of the nature of competition } \\
\hline V.A. Gretskiy [6, p.36] & $\begin{array}{l}\text { An economic group that manages productive relations between the commodity produce } \\
\text { in the course of the exchange of goods of labor }\end{array}$ \\
\hline G.M. Filyuk [4, p. 404] & $\begin{array}{l}\text { An analysis of the entity's management of its own competitive advantage for achieving } \\
\text { objectives in the fight against competitors for the satisfaction of objective or subjective } \\
\text { needs }\end{array}$ \\
\hline D.A. Panasenko [7, p. 271] & $\begin{array}{l}\text { Political and economic relations among the countries in terms of getting the best } \\
\text { conditions on the markets for themselves, and their producers }\end{array}$ \\
\hline V.A. Adamek [8, p. 70] & $\begin{array}{l}\text { The rivalry in each field of labor between individual legal entities or individuals } \\
\text { (competitors) having an interest in achieving one goal }\end{array}$ \\
\hline R.A. Fatkhutdinov [9, p. 503] & $\begin{array}{l}\text { Investigates competitiveness as a feature of an object that is characterized by the degre } \\
\text { of actual or potential satisfaction of a defined demand with respect to similar objects thi } \\
\text { are represented in this market [7, p.35]. He emphasizes that the competitiveness of an } \\
\text { enterprise is his ability to produce competitive products. }\end{array}$ \\
\hline
\end{tabular}




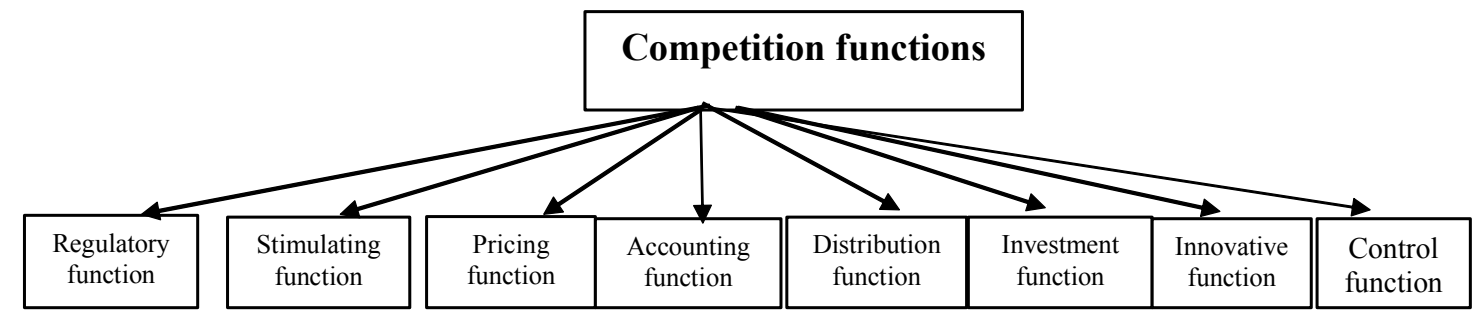

The functions of competition as an economic category

understood through the functions it performs (Figure).

The leader must understand the requirements of consumers and recommend products that meets these requirements. Thus, with help of the regulatory function, the factors of production under the influence of prices are targeted at those industries the development of which is most in need.

The stimulating function (or motivation function) forces economic entities to reach the maximum productivity. For industrialists, competition is, at the same time, the opportunity and risk, that means that business entities who achieve higherquality products or produce less waste receive income and, conversely, receive penalties in the form of damages, if they disregard the wishes of buyers or non-compliance laws of competition by own competitors in the market.

With the help of the pricing function, competition affects the level of individual costs for the production of any product, reducing them to socially necessary, which, in turn, determine the balanced market price of the product.

Due to the distribution function, competition distributes profits among enterprises in line with their productive contribution, which corresponds to the key competition rule - reward results.

Competition acts like force, with the help of control, which will resist the emergence of sustainable economic power of individual market players. Consequently, competition controls and limits the economic potential of each entity. In particular, if a monopolist has the opportunity to establish a single possible cost, then the competition allows the buyer to choose between several vendors.

The function of accounting involves the collection and analysis of information on the results of current activities, the arrangement of internal accounting of the organization and its divisions.

The function of investments allows to finance new projects.

Innovative function is promoting innovative technologies. For the possibility of obtaining additional income, while not increasing the cost of production, it is necessary to continuously upgrade the technological base of the enterprise, introduce modern technologies and progressive forms of organization of the production process, thereby reducing the company's business. Entrepreneurs who carry out such activities receive additional income. At that time, entrepreneurs who will not be able to implement such measures will be pushed out of the market. Consequently, competition is a force that provides scientific, technical and economic progress.

It is worth emphasizing (note) that the main task and the main function of competition - is to conquer the market, win its competitors in the competition for its consumer, ensuring the obtaining of stable profits.

By performing the functions presented, competition directly affects the production capacity, improving its technical level, providing improved quality and expansion of the product range [10, p. 123].

Factors that have an impact on competition can be divided into two categories: internal and external.

External factors - these are factors that the company cannot influence and, in its policy, should treat them naturally. These include the following:

1) Functioning of state deposit organizations (fiscal and monetary policy, legislation). For example, from the circumstances of the tax policy (tax rates), the company will receive high profits or, conversely, not get it at all.

2) Economic conditions, which include the situation of commodity and material markets, labor market sources, means of production markets, financial capacity markets.

3) Development of family and support industries. In this option, it is the development of new technologies (resource saving, deep processing technologies), new raw materials and energy sources, their introduction into the production of products, increasing the scientific and production potential of the enterprise.

4) Demand requirements. These include increased demand for products manufactured by the company, its stability, which in general gives the company the opportunity to receive high profits, as well as to prove itself on the market. Unstable demand, changing the preferences of the buyer to the quality of goods of the enterprise, the decline of the purchasing power of people, by contrast, do not create conditions for certain competitiveness of enterprises [4, p.171].

The internal factors include the following:

1) The operation of the management and the 
control of the enterprise (organizational and production management organization, professional and qualified level of managerial staff).

2) System of technological equipment. Upgrading equipment and technologies, that is, replacing them with more advanced ones, ensures increased competitiveness of the enterprise, strengthens the internal flexibility of production.

3) Sales of products, their quantity and sales costs. This indicator has a significant impact on the competitiveness of the enterprise: it is possible to achieve significant performance in production, producing better quality products and relatively low cost, but all this will be undone due to the unwise policy of product sales.

It is worth mentioning the market power which satisfies the interaction of supply and demand balances market prices is the law of competition. This economic law characterizes a significant causeand-effect necessary to stabilize the link between production and sales of products.

The desire of the leadership to move towards increasing labor productivity, expanding production volumes at its facilities, accelerating scientific and technological progress, introducing new production technologies, new production organization principles, classification of wages, etc. are a sequence of external forces, under which the law of competition arises from [5, p. 93].

The introduction of the competition law in general allows industrial enterprises to realize their economic availability of diverse production costs and to form differences in the value of the produce that they produce.

This justification operates under conditions of a market economy that is not capable of developing the same conditions for all producers and sellers, for the reason that the law of value is in force. Buyers prefer what they like. Thus, the discrepancy between the ability to produce products, the providing of services and the options of their sales is justified.

Some scholars, in particular: M. Porter, J. Lamben, P.S. Zavyalov, R.A. Fatkhudinov, identify the competitiveness and competitive advantage at a separate level, their position is that the competitive preference is the nature of products, by which, it makes it more useful to the buyer, in contrast to similar products of rivals. After analyzing such an approach, it is worth highlighting the following properties of competitive advantages:

- Competitive advantage is an element in the system of competitive relations;

- Competitive advantage comes into force in a competitive environment;

- Competitive advantage is relative;

- The competitive advantage is energetic.

Noteworthy various approaches of scholarly economists that combine competitive advantages with competitiveness. However, in my opinion, there are differences between these concepts. In the interpretation of causation, it is worth pointing out that competitiveness is the result, which confirms the presence of competitive priorities, in the absence of which competition is impossible.

In studying the process of creating competitive advantages, one of the main factors is the disclosure of the factor of their actions on competitiveness and their internal communication.

The presence of some competitive advantages does not guarantee the competitiveness, which is influenced by environmental factors: competitive, technological, political, economic, market.

Each economic entity, industry, type of production in particular and the economy as a whole have competitive advantages as well as competitiveness, and based on this, these definitions can be considered at personal, micro and macro levels.

Competitive advantages help to achieve competitiveness, and in their definition, they are primary.

Competitiveness of goods has a definition of competitive advantages that have a certain type of goods, on the one hand it is quality, on the other, the price. Also, the benefits of advertising have an impact on the competitiveness of goods, a service that guarantees the maintenance of goods in the warranty and post-warranty period, which allocates this product among other goods.

According to the scientist Pozhueva T.A., if an industrial enterprise can form a rather high competitive status, i.e. to preserve, under all conditions, its dynamically stable position in the competition for the output and sale of finished products, then its competitive advantages will become a solid core of long-term protection of this economic entity among a group of enterprises- competitors of a similar industry and determines its further economic success $[11$, p. 326].

On this basis, competitive advantages have the leading places. On the one hand, the competitive advantages of business entities does not prevent it from gaining competitive ability, on the other competitive advantages always represent the result of a well considered and implemented competitive plan.

Thus, the basis of management of an enterprise in a competitive environment is the theoretical regulation and scientifically substantiated systematization of competitive advantages, and the use of developed scientific approaches in practice contributes to the achievement of competitiveness.

\section{Conclusions}

Competition forces commodity producers to introduce innovative processes and technologies to reduce production costs. In general, this approach tends to improve the quality of the product, attract new customers and increase its own profits. In a 
competitive environment, competitiveness always manifests itself, and at different levels, which must be considered when managing it.

The article states that the competitiveness of the enterprise is a complex variable concept, which means rivalry, struggle for achievement of the best results, obtaining competitive advantages by effectively using all available resources, manufacturing and realization of competitive products and making profit from conducting effective economic activity. In general, competitiveness is one of the main components of the success of any enterprise.

\section{REFERENCES}

1. Shershnyova Z.E. (2004). Stratehichne upravlinnia [Strategic management]: Textbook / Shershnyova Z.E. - 2nd form., Processing and add. - K.: KNEU, p.699 [in Ukrainian].

2. Azhnyuk M.O. (2008). Osnovy ekonomichnoi teori [Fundamentals of Economic Theory]: Teachers. / M.O. Ajnyuk, O.S. Prorryi. - Kyiv: Knowledge, p.368 [in Ukrainian].

3. Mochernyy S.V. (2003). Ekonomichna teoriia [Economic theory]: Manual / S.V. Mochernyy-K.: Publishing Center «Academy», p.656 [in Ukrainian].

4. Filyuk G.M. (2011). Konkurentsiia i monopoliia v epokhu hlobalizatsii [Competition and monopoly in the era of globalization]: monograph / G.M. Filyuk - Zhytomyr: View at ZHDU I. Franko, p.404 [in Ukrainian].

5. Shved V.V. (2013). Konkurentospromozhnist pidpryiemstva ta osoblyvosti yikh vyznachennia $\mathrm{v}$ suchasnykh umovakh [Competitiveness of the enterprise and the peculiarities of their definition in modern conditions] / V.V. Shved, S.L. Yablohnikov // Bulletin of the University of Dnipropetrovsk. Issue 7/1. - (pp.92-97) [in Ukrainian].

6. Gretsky R. (2015). Teoretychni pidkhody do vyznachennia pryrody ta sutnosti konkurentsii [Theoretical approaches to the definition of the nature and essence of competition ] / R. Gretsky // Formation of market relations in Ukraine. - No. 2. - (pp. 35-38) [in Ukrainian].

7. Panasenko D.A. (2012). Konkurentospromozhnist pidpryiemstva: sutnist ta funktsionalna kharakterystyky [Competitiveness of the enterprise: essence and functional characteristics ]/ D.A. Panasenko // Bulletin of the National University «Lviv Polytechnic”.- Lviv: Lviv Polytechnic Publishing House. - No. 727- (pp.270-276) [in Ukrainian].

8. Adamik V.A. (2012). Otsinka konkurentospromozhnosti pidpryiemstva [Assessment of the Competitiveness of the Enterprise] / V.A. Adamik // Bulletin of the Ternopil National Economic University. - No. 1.- (pp.69-78) [in Ukrainian].

9. Fatkhudinov R.A. (2005). Stratehycheskaia konkurentosposobnost [Strategic Competitiveness]: Study. on specialty «Marketing» / R.A. Fathutdinov M.: Economics. - p.503 [in Ukrainian].

10. Puctenteylo P. (2013). Konkurentsiia yak ekonomichna katehoriia [Competition as an Economic Category] / P. Puctenteylo // Economy of AIC. - No. 4. - (pp.122-126) [in Ukrainian].
11. Pozhueva T.A. (2014). Konkurentospromozhnist pidpryiemstva odyn iz holovnykh zovnishnikh indykatoriv diahnostyky ekonomichnoi zakhyshchennosti [Competitiveness of the enterprise is one of the main indicators of the diagnostics of economic security] / T.A. Pozhueva // Strategii si politici de management in economia contemporana Prilejuita de implinirea a 70 de ani de la nasterea regretatului prof. univ., dr. hab., mem. Coresp. al ASM, Rector ASEM (1994-2001) Eudgen HRISCEV 28-29 MARTIE 2014, Editura ASEM, Chisinau. - (pp. 323327) [in Chisinau].

Received 20.10.2018

Reviewer: Doct of Econ.Sc., prof. Garmider L.D.

\section{ПОНЯТТЯ І СУТНІСТЬ ФОРМУВАННЯ КОНКУРЕНЦІЇ НА ПРОМИСЛОВОМУ ПІДПРИЕМСТВІ}

Ткаченко А.М., Колесник Е.О.

Стаття присвячена дослідженню теоретичних аспектів конкуренції та ї̈ ролі в умовах ринку. Проаналізовано основні підходи до методології дослідження конкуренції та конкурентоспроможності підприємств. Розглянуто основні види та функції конкуренції в сучасних умовах. Визначено чинники які впливають на формування конкуренції. Проаналізовано фактори, які найбільше впливають на конкуренцію в ринкових умовах. Розглянуто закон конкурениії. Проаналізовано конкурентні переваги. В статті наголошено, що конкурентоспроможність підриємства - це складне багатоаспектне поняття, яке означає суперництво, боротьбу за досягнення найкращих результатів, отримання конкурентних переваг шляхом ефективного використання всіх наявних ресурсів, виготовлення та реалізації конкурентоспроможної продукції та отримання прибутку від ведення ефективної господарської діяльності. Загалом конкурентоспроможність - це одна з головних складових успіху будь-якого підприємства.

Ключові слова: конкуренція, ринок, змагання, конкурентоспроможність підприємств, механізми ринку, конкурентні переваги.

\section{ПОНЯТИЕ И СУЩНОСТЬ ФОРМИРОВАНИЯ КОНКУРЕНЦИИ НА ПРОМЫШЛЕННОМ ПРЕДПРИЯТИИ}

\section{Ткаченко А.М., Колесник Э.А.}

Статья посвящена исследованию теоретических аспектов конкуренции и ее роли в условиях рынка. Проанализирова ны основные подходы кметодологии исследования конкурениии и конкурентоспособности предприятий. Раскрыты основные виды и функции конкуренции в современных условиях. Определены факторы, влияющие на формирование конкуренции. Проанализировано факторы, которые больше всего влияют на конкуренцию в рыночных условиях. Рассмотрен закон конкуренции. Проанализированы конкурентные преимущества. В статье отмечается, что конкурентоспособность предприятия это сложное многоаспектное понятие, означающее соперничество, борьбу за достижение лучших результатов, получение конкурентных преимуществ путем эффективного использования всех имеющихся ресурсов, производства и реализации конкурентоспособной продукции и получения прибыли от ведения эффективной хозяйственной деятельности. В целом, конкурентоспособность - это одна из главных составляющих успеха любого предприятия.

Ключевые слова: конкуренция, рынок, соревнование, конкурентоспособность предприятий, механизмы рынка, конкурентные преимущества. 